\title{
Línguas Orientais: linhas de pesquisa
}

\section{BEATRIZ DINIZ}

\section{A linhas de pesquisa do Departamento de Línguas Orientais es- tão centradas na seguintes áreas: \\ 1 Lingua e Literatura Árabe:}

- Língua árabe (elaboração de método de ensino de língua árabe para alunos lusófonos; análise de um tópico fundamental de gramática árabe - o verbo e a variabilidade da raiz).

- Literatura árabe (a identidade cultural presente na literatura magrebina; antologia de textos clássicos da literatura árabe).

- Cultura árabe (multiculturalismo brasileiro - fisionomia e diretrizes - a presença árabe em nosso meio; a produção cultural do imigrante árabe no Brasil; pensamento árabe e pensamento ocidental; medieval - projeto realizado em colaboraçáo com o Departamento de Filosofia e Ciência da Educação da Faculdade de Educaçăo da USP).

\section{Lingua e Literatura Armenia:}

- Língua armênia (fonética e fonologia).

- Lingüística aplicada (ensino da língua armênia para estudantes brasileiros).

- Linguística histórica (a posição do armênio dentro do indo-europeu - estudo contrativo fonético-fonológico).

- Literatura armênia (a literatura armênia e a modernidade; Alícia Ghiragossian - uma armênia na Armênia; a produçáo literária dos armênios no Brasil).

- Cultura armênia (a pintura de Martiros Saraian; a contribuiçáo da arqueologia para a cultura armênia; autores gregos e latinos que se referem a assuntos armênios; o paganismo na formaçáo cultural da Armênia e suas projeçóes).

- Dicionário histórico-geográfico sobre a Armênia.

- Bibliografia armênia.

\section{Lingua e Literatura Chinesa:}

- Língua chinesa (fonética; ensino da língua chinesa moderna e clás- 
sica; conversação; dicionário português-chinês).

- Literatura chinesa (história da literatura chinesa; literatura moderna chinesa; literatura clássica chinesa; análise literária).

- Cultura chinesa (introdução de história da China; pintura e caligrafia chinesa; vida cotidiana do povo chinês; os grandes pensadores chineses; imigração chinesa).

- Bibliografia.

\section{Lingua e Literatura Hebraica:}

- Antropologia urbana (imigraçáo judaica).

- Ensino e aprendizagem (o ensino da língua hebraica).

- Fundamentos da educaçáo (bases judaicas na educaçáo).

- História moderna e contemporânea (imigração judaica).

- Língua estrangeira moderna (o ensino da língua hebraica).

- Linguística aplicada (o ensino da língua hebraica; dicionário hebraico/português).

- Linguíística Histórica (projeçóes da Bíblia).

- Literatura estrangeira moderna - Literatura hebraica (tradução; história; aspectos da história na literatura; gêneros literários; modernismo; costumes e comunidades) e Literatura norte-americana (aspectos judaicos).

- Teologia moral (aspectos bíblicos).

- Teoria e análise lingüística (dicionário hebraico/português).

\section{Lingua e Literatura Japonesa:}

- Língua japonesa (morfossintaxe; semântica; análise do discurso; sócio lingüística).

- Literatura japonesa (poética clássica; Setsuwa - narrativa medieval; literatura moderna; história da literatura.

- Arte Japonesa (teatro clássico - nd, kjogen, kabuki; xilogravura ukiyo-e).

- História japonesa (formação do Estado e do sistema imperial japonês).

Beatriz Diniz é professora do Departamento de Línguas Orientais da Faculdade de Filosofia, Letras e Ciências Humanas da USP. 